\title{
Transatlantic Relations after the War in Iraq
}

\author{
by Thérèse Delpech*
}

After the war in Iraq, there is a troubling difference between the internal and the external assessment of the state of transatlantic relations - that is to say, a difference between the perceptions of those involved in the transatlantic dynamic (Europeans and Americans) and those outside it. To most Americans and Europeans, the transatlantic bond has been badly damaged. Cooperation in some shape or form still appears possible on a number of issues, but even now, months after the end of hostilities, the stubborn insistence of the different actors to find their position on the war vindicated by events continues to poison the atmosphere. Worse, dangerous questions for NATO have now surfaced concerning the indivisibility of European and American security.

More than ten years after the end of the Cold War, it seems that we now have more than different views on security between the U.S. and Europe; we have diverging interests and values. And, to some observers, the choice appears to be between an amicable separation or a nasty divorce. To measure the extent of the damage, it suffices to note that a senior British diplomat, Rodric Braithwaite, wrote in the May issue of Prospect: "The special relationship is now supported only by Prime Ministers, submariners, and code breakers."

By contrast, to many located someplace other than the North Atlantic littoral (broadly defined), such transatlantic disputes are not only senseless but worrisome. They are simply a luxury that rich and prosperous nations can afford - precisely as a luxury - that reveal a concealed contempt for the more difficult situation faced by a large part of the world ("the West and the rest"). Some Iraqis may currently be the most vocal in expressing this feeling openly: "Stop quarrelling and start rebuilding our country for good!" Already, in March, when a second resolution was discussed, the non-permanent members of the United Nations Security Council made it clear that they did not see any reason to take a firm stand on the issue, since the major powers, and in particular Western nations, could not agree among themselves. Later on, India also expressed dismay at the sharp division among the world's democratic nations. At a time when New Delhi was striving to shed the post-colonial mindset in order to adopt a more proactive and responsible foreign policy, the transatlantic inability to agree on the way to enforce a Security Council resolution was disturbing.

One is hardly surprised by such reactions. It was not dignified to undertake diplomatic campaigns for Security Council votes in countries like Guinea, Cameroon, Angola, and Chile. Among allies, it should have been possible to reach at least one of the two far better following outcomes: either col-

\footnotetext{
* Thérèse Delpech is Senior Research Associate at the Centre d'Études et de Recherches Internationales (CERI) in Paris.

${ }^{1}$ Rodric Braithwaite, 'End of the affair', Prospect, May 2003, pp. 20-23.
} 
lective pressure on Saddam strong enough to convince him to give up, or collective forceful action against Baghdad. Unity was important because the alliance of Western democracies is needed to provide stability far beyond Iraq.

Even if America and its allies would be well advised to discover some rapprochement for the rebuilding of Iraq, and even if success or failure there were to have more than regional consequences, the task is much bigger. In a turbulent world, significant international responsibilities fall upon the West with the envied status of being an island of peace, wealth, and democracy - an island with three permanent seats on the Security Council, it should be noted. Western powers should therefore not only recognize that they are all affected by post-Cold War turbulence - this alone could justify continued cooperation among them - but especially that they are in the driver's seat when it comes to responding to international crises and reducing international tensions.

With the evolution of Western demography - the significant aging of the U.S. population, and the much more dramatic case among European populations - the temptation to care only about national interests, with a relative indifference to the rest of the world, may increase. But in light of globalization, international terrorism, and WMD proliferation, it will also become increasingly difficult to escape international responsibilities.

Globalization does not end geopolitics. It makes it more complex. Everything tends to affect everything else: madrasas in Pakistan, SARS in China, sensitive exports from North Korea. International terrorism, with its ruthless disregard for human life and its rigid fanaticism, is aimed at the values that democracies hold dear. And as far as proliferation is concerned, it appears that one crisis will continue to follow another. Yesterday it was Iraq. Today it is Iran and North Korea. Tomorrow, it may be Egypt, Saudi Arabia, and Japan. Iraq will still be with us for at least a decade, and Iran and North Korea have the ability to pose problems that could affect security far beyond the regions to which they belong. Their access to nuclear weapons would simply mean the explosion of the non-proliferation regime; a nuclear Iran would most probably lead Cairo and Riyadh to rethink their international commitments concerning the NPT, and a nuclear North Korea could have the same effect on Japan. The consequences in terms of increased instability in two of the most volatile regions of the world are not difficult to foresee.

Although Americans often forget it, most of the world's problems are abroad. Europe knew it all too well for centuries, but it should now come around again to the same conclusion. This will not be easy. Why? Because after having been devastated by war for centuries, with approximately one significant conflict per generation, Europe's deepest wish is to feel unthreatened. Although the idea of Europe may have originally been conceived to make conflict impossible among its members, security has in many ways been an afterthought. Reform of EU governance, enlargement toward the east, and completion of the Euro-currency zone have taken precedence over security issues. Until recently (1998), 
the European security debate was focused on institutional progress.

It took the decade-long Balkan wars to awaken Europe to the new security challenges. In principle, the European Defense Policy will make Europe increasingly capable of taking care of itself, allowing (at least in the best-case scenario) a new division of labor on global security issues, with more European involvement than in the past. However, the huge demonstrations that took place across Europe against the war in Iraq signaled a wider problem than just disagreement over Iraq. They also show that there may be more problems than simple financing difficulties and low and declining defense budgets on this side of the Atlantic. Europe has entered the twenty-first century safer than at any time in its history and wants to remain that way, come what may. Reluctance to look beyond European borders, or rather beyond the immediate European periphery (the Mediterranean, the Balkans, and Russia), is still widespread. The problem here is not one of too much American military power, but rather insufficient European capabilities and lack of sufficient will to share responsibilities for solving international crises.

As is well known, even the most current documents on European defense include no threat assessments, because the subject remains far too divisive. Contrary to what happens in the United States, where threats are often overemphasized, in Europe they tend to be overlooked. This characteristic is reinforced by the presence within the European Union of countries like Austria, Ireland, Sweden, and Finland, who believe that any common security and defense policy should be restricted to peacekeeping operations outside EU territory. There is an additional reason for this situation. Although threat assessment is not a science, it does rely on military, technical, and political knowledge, which requires good intelligence. And strategic intelligence is hardly a European strength, particularly at the collective level, although September 11 has encouraged significant intelligence sharing. From this viewpoint, it was encouraging to learn that, at the end of June, Javier Solana was asked to produce, for the first time, a European security strategy, which is supposed to be formulated by December 2003. But what will be actually possible for all Europeans to agree on remains to be seen.

More than three years ago, in April 1999, the aim of the NATO Washington Summit Communiqué was to define "an Alliance for the twentyfirst century," taking into account the major strategic changes of the past ten years. At the time, the most important transatlantic debate concerned missile defense, and it was already a very sour discussion. The plan was extremely controversial in Europe, and criticism was toned down only when Russia accepted - without much fanfare - U.S. withdrawal from the 1972 ABM Treaty. Then there was no way to be "more royalist than the king," as the French used to say. But since 1999, two major events have occurred: 11 September 2001 and the removal of Saddam Hussein from power in Iraq. The latter has left the Alliance deeply divided, both within Europe and across the Atlantic. The former has pro- 
foundly changed the U.S. by introducing a strong feeling of vulnerability, both at home and abroad. Europeans have seldom understood the magnitude of the change, either within America or in the radical nature of the phenomenon itself. The ability of non-state actors to pose not only tactical but strategic challenges to the most developed nations is indeed a major strategic change, and one that will be with us for decades.

It is true that transatlantic cooperation on non-proliferation issues has been improving dramatically in the last ten years. Although non-proliferation is widely perceived in Europe as primarily an American invention, it was gradually adopted by all European nations over the past decade. The non-proliferation fight became a diplomatic objective and a growing security concern for both the United States and Europe, and their respective policies became increasingly intertwined.

As recently as June 2003, a joint U.S.-EU statement on WMD proliferation reaffirmed the transatlantic collective view on the subject. But as a matter of fact, difficulties arise when nations face the famous question raised by Fred Iklé in his seminal article published in 1961 in Foreign Affairs: "After Detection, What?"2.

Iraq's violation of its international obligations was recognized in November 2002 by the fifteen members of the Security Council, and Baghdad's December 7 declaration was unanimously found lacking: answers to the numerous questions that the UN had been asking since 1991 were not there. North Korea withdrew from the NPT in January 2003 after having been found in violation of its obligations under the Treaty. Needless to say, withdrawal in such a situation is illegal. And there is no doubt that Iran has violated both its safeguards agreement with the IAEA and its NPT obligations.

The lack of willingness to enforce treaties by collective diplomatic pressure before other means are contemplated is one of the main reasons that military action against proliferators is seen as necessary. Procrastination and indecisiveness are the causes. In addition, it is a most dangerous trend in terms of the multilateralism that Europeans rightly cherish. Multilateralism should not be a way to delay solutions or diffuse problems, but rather to solve them.

There are other issues where transatlantic cooperation is needed, but I will only mention a few of them. In Afghanistan, as NATO takes over the Kabul-based International Security Assistance Force by late summer, the opportunity should be seized to extend the peacekeeping role beyond the capital to regions dominated by local warlords. In the Middle East, the cooperation on peace-making has achieved some progress with the presentation of the Quartet's "road map" to the parties. The process has entered a new phase, with significant steps towards ending the cycle of violence being contemplated. However, the extent to which it will succeed will depend not only on the Israelis and the

${ }^{2}$ Fred Iklé, ‘After Detection, What?', Foreign Affairs, January 1961, pp. 208-220. 
Palestinians, but also on the sustained involvement of the primary external actors. Last but not least, cooperation on making development aid more effective and dismantling barriers to trade would fulfill a significant responsibility of wealthy nations. Through the Millennium Challenge Account, the U.S. and Europe should increase development assistance and direct it where it will make the greatest difference. The Doha round of talks should also lead the transatlantic partners to limit trade barriers and to help the Middle East to diversify its regional economy beyond oil.

A number of unpleasant surprises may be lying ahead, but international cooperation remains the surest chance to successfully face them. The ability of potential adversaries to challenge Western powers in surprising ways is increasing. Alliances are needed perhaps more than ever to prevent them from succeeding. The U.S. requires the consent of others - in the first place, the Europeans - to succeed in implementing a complex security agenda. But, on the other side, the Europeans should also draw the necessary conclusions about the consequences of the strategic landscape as it now stands: Insecurity having been globalized, a global vision and adequate force projection are required to meet the threat. And if the use of weapons of mass destruction is more, not less, likely than it was during the twentieth century, non- and counter-proliferation policies should receive higher priority on the security agenda and in the minds of European and American leaders. 
THE QUARTERLY JOURNAL

\section{Bibliography}

Braithwaite, Rodric. "End of the affair." Prospect (2003): 20-23.

Iklé, Fred. "After Detection, What?" Foreign Affairs (1961): 208-220. 